\title{
THE EFFECT OF PINDOLOL ON PLASMA RENIN ACTIVITY AND BLOOD PRESSURE IN HYPERTENSIVE PATIENTS
}

\author{
R. LANCASTER, T.J. GOODWIN ${ }^{1}$ \& W.S. PEART \\ Department of Medicine St Mary's Hospital, London W2 1NY
}

\begin{abstract}
1 The effect of pindolol administered to twenty-six patients with hypertension of unknown origin was compared with respect to blood pressure and plasma renin activity change after increase of the dose over a period of 6 weeks.

2 There was no clear correlation between the fall of plasma renin activity, which in some patients was very marked, and the fall in blood pressure. Some patients with a fall in plasma renin activity did not drop their pressure. Conversely, some with a fall of pressure did not drop their plasma renin activity.

3 The addition of hydrochlorothiazide to the pindolol finally caused further lowering of the blood pressure in all but one patient and the plasma renin activity rose in all but two patients. There was no clear correlation between change in plasma renin activity and the effect on blood pressure.
\end{abstract}

\section{Introduction}

The release of renin from the kidney is stimulated by $\beta$-adrenoceptor agonists such as isoprenaline (Winer, Chokshi \& Walkenhorst, 1971), and conversely some $\beta$-adrenoceptor blocking drugs are very effective in preventing or reducing renin release not only by isoprenaline (Winer et al., 1971; Ganong, 1972), but during the ordinary activities, such as change of posture, of normal subjects (Michelakis \& McAllister, 1972). Since the initial statement that $\beta$-adrenoceptor blocking drugs like propranolol might be used with the expectation that they would reduce the blood pressure selectively in patients with high plasma renin activity and would be relatively ineffective in those with normal or low plasma renin activity (Bühler, Laragh, Baer, Vaughan \& Brunner, 1972; Bühler, Laragh, Vaughan, Gavras, Brunner \& Baer, 1973), many investigations have been undertaken to test this statement and the results have been conflicting. It has been claimed that some $\beta$-adrenoceptor blocking drugs will lower the blood pressure without affecting plasma renin activity, and conversely, that even when plasma renin activity is lowered, the blood pressure may

* Present address: Harefield Hospital, Harefield, Middlesex be little affected (Hansson \& Zweifler, 1974; Stokes, Weber \& Thornell, 1974). One of the problems with this sort of study is that $\beta$-adrenoceptor blocking drugs are rather diverse in their activity and may have $\beta$-adrenoceptor stimulating effects, for example on the heart, so if the variable effects on the central nervous system are added to this (Frohlich, Tarazi, Dustan \& Page, 1968; Julius, Pascual, Abbrecht \& London, 1972; Tarazi \& Dustan, 1972; Day \& Roach, 1973; Dollery, Lewis, Myers \& Reid, 1973), it is perhaps not surprising that there is variability in the relation of blood pressure and plasma renin activity in different studies. Propranolol will block renin release induced by either isoprenaline in the isolated perfused kidney (Vandongen, Peart \& Boyd, 1973) or renal sympathetic nerve stimulation (Johns \& Singer, 1974). It was thought worth while to examine the effects of pindolol, a non-selective $\beta$-adrenoceptor blocking drug, with some intrinsic sympathetic activity but producing a longer duration of $\beta$-adrenoceptor blockade than propranolol, in an unselected group of hypertensive patients, comparing the hypotensive effect with plasma renin activity after some weeks of treatment. 


\section{Methods}

\section{Entry to the trial}

The subjects were selected on the basis of a raised blood pressure for which no cause had been discovered on investigation. They were of either sex (seventeen female nine male), between the ages of 26 and 67 years. Of the twenty-six patients studied, nineteen were white European, the remainder being African, Indian or Chinese. The nature of the trial was explained to each patient and agreement to its form had been received from the Ethical Committee of the Hospital.

\section{Form of the trial}

The patients were not receiving any medication for high blood pressure at entry and at this time, as part of the investigation, blood was taken for plasma renin activity after $1 \mathrm{~h}$ of recumbency between 09.00 and 10.00 hours. Blood pressure was taken in the sitting and standing position, as was the pulse rate. No one was entered into the trial unless two consecutive sets of readings on different occasions indicated that treatment for high blood pressure would ordinarily be undertaken. At this stage treatment was commenced with pindolol placebo tablets, indistinguishable from the active compound and taken three times a day as with the active compound. The placebo treatment lasted between 2 and 4 weeks and then pindolol was substituted in an initial dose of $5 \mathrm{mg}$ t.d.s., rising usually at two to four weekly intervals to $10 \mathrm{mg}$ and $15 \mathrm{mg}$ t.d.s. The plasma renin activity was then measured again under the same conditions when the final dose of pindolol at $15 \mathrm{mg}$ t.d.s. had been given for at least 2 weeks.

\section{Effect of thiazide}

In fifteen of the subjects, hydrochlorothiazide in a dose of either $25 \mathrm{mg}$ or $50 \mathrm{mg}$ daily was added to the pindolol to see the effect on blood pressure and plasma renin activity after the combination had been administered for at least 2 weeks.

\section{Measurement of blood pressure}

This was measured by two observers in two different hospitals and the pressures were taken in the sitting and standing positions. The diastolic pressure was taken as the point of muffling. The pressure was measured with either an ordinary sphygmomanometer and the values noted without knowledge of previous readings or other data on the patient at each visit, or with a 'random zero' apparatus (Hawksley \& Son, Ltd). The pulse rate was measured on arrival at the clinic in the sitting and standing position by a nurse before blood pressure was taken.

\section{Results}

\section{Effects on blood pressure}

A comparison was made between the blood pressure taken at the end of the placebo period and that taken at the end of the administration of pindolol. Out of the twenty-six patients, five had a fall in systolic pressure and diastolic pressure greater than $20 \%$; ten had a fall in systolic pressure and diastolic pressure of $10-20 \%$; three had a fall greater than $10 \%$ in systolic pressure and $5-10 \%$ in diastolic pressure; while in eight there was a fall in blood pressure of less than $5 \%$ or even a rise in pressure. In the group as a whole there was a $12.1 \pm$ (s.d.) $8.75 \%$ fall in mean (diastolic + one-third of pulse pressure) sitting blood pressure and a $13.0 \pm$ (s.d.) $8.63 \%$ fall in the mean standing blood pressure, the difference between the two positions not being statistically significant $(P>0.5)$.

\section{Pulse rate}

There was a highly significant fall in the average sitting pulse rate/min from $92 \pm$ (s.d.) 20 to $77 \pm$ (s.d.) $12(P<0.005)$ and in the average standing pulse rate from $94 \pm$ (s.d.) 19 to $80 \pm$ (s.d.) $12(P<0.01)$. The pulse rate fell in all but one subject in the sitting and in all but two subjects in the standing position.

\section{Renin levels}

The normal range of renin by the method used (Boyd, Adamson, Fitz \& Peart, 1969) is 200-600 pg ml ${ }^{-1} 24 \mathrm{~h}^{-1}$ as $\mathrm{AI}$ and it can be seen that six of these subjects lay above this range and ten below it (Table 1). Twenty out of twenty-six subjects showed a fall in plasma renin level on pindolol, there being an average fall in renin from $350 \pm$ (s.d.) $355 \mathrm{pg} \mathrm{ml}^{-1} 24 \mathrm{~h}^{-1}$ to $161 \pm$ (s.d.) 209 $\mathrm{pg} \mathrm{ml} \mathrm{m}^{-1} 24 \mathrm{~h}^{-1}(P<0.025)$. A regression plot of the percentage change in mean sitting blood pressure on pindolol versus the percentage change in plasma renin activity (Figure 1) showed no statistically significant relationship between these values $(r=0.11, P>0.1)$. Similarly there was no significant correlation between percentage change in mean standing blood pressure and the change in plasma renin activity. There was a greater fall in 


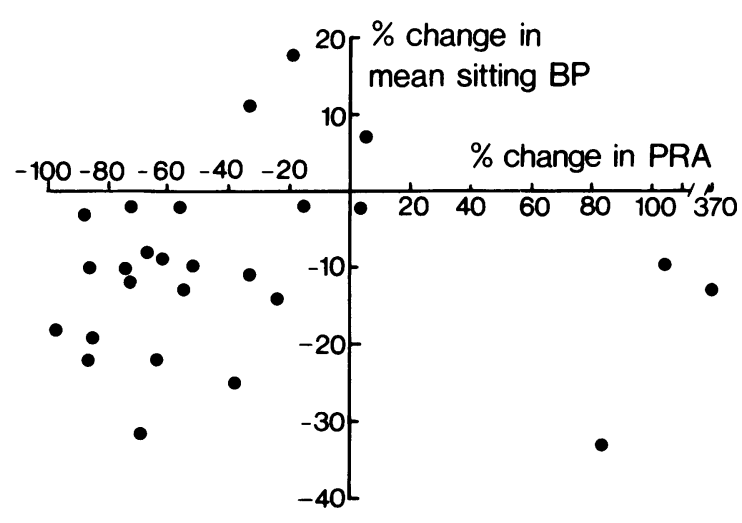

Figure 1 A regression plot of pindolol induced changes in mean sitting blood pressure and plasma renin activity (PRA), $(n=26, r=0.11, P>0.1)$.

the mean standing blood pressure $12.3 \pm$ (s.d.) $14.8 \%$ for the high renin group than for the normal renin $7.89 \pm$ (s.d.) $13.3 \%$ and the low renin group $6.0 \pm$ (s.d.) $11.7 \%$, but these differences were not statistically significant $(P>0.3)$. A regression plot of percentage change in mean standing blood pressure against pre-treatment plasma renin activity was just significant at the $10 \%$ level $(r=0.32)$.

\section{Effects of pindolol plus a thiazide}

In fifteen patients hydrochlorothiazide was added $(25-50 \mathrm{mg} /$ day) without potassium supplements and the effect on blood pressure and plasma renin activity measured between 2 and 4 weeks afterwards. There was a fall in the mean sitting blood pressure of $10.1 \pm$ (s.d.) $8.6 \%$ and in the mean standing blood pressure of $14.7 \pm$ (s.d.) $9.9 \%$ on hydrochlorothiazide, the difference in the fall in the two positions not being significant $(P>0.2)$, and there was no change in the sitting pulse rate, the pre-thiazide rate being $77.1 \pm$ (s.d.) 11 , and the post-thiazide rate $76 \pm$ (s.d.) 16 (Table 2). There was a statistically significant rise in plasma renin activity from $128 \pm$ (s.d.) $141 \mathrm{pg} \mathrm{ml}^{-1} 24 \mathrm{~h}^{-1}$ to $409 \pm$ (s.d.) $368 \mathrm{pg} \mathrm{ml}^{-1} 24 \mathrm{~h}^{-1}(P<0.01)$ but there was no correlation between the change in the mean blood pressure and the change in plasma renin activity in either the sitting $(r=0.1)$ or the standing positions $(r=0.2)$. Furthermore, there was no correlation between the fall in blood pressure in either position and the pre-thiazide plasma renin activity.

\section{Side-effects}

Only two patients had side-effects sufficient to stop the drug (patients 3 and 4, Table 1), both because of hallucinations which ceased immediately the drug was stopped.

\section{Discussion}

With long term administration of pindolol, plasma renin activity is reduced and in many instances to very low levels (Weber, Thornell \& Stokes, 1974; Morgan, Roberts, Carney, Louis \& Doyle, 1975; Werning \& Vetter, 1975). Some of the patients in the present trial had repeat renin measurements made after the treatment had been maintained for some months with continued low levels. While there is known pharmacological variation in $\beta$-adrenoceptor blockers and probably in their ability to suppress renin activity (Bühler et al., 1972; Michelakis \& McAllister, 1972; Amery, Billiet \& Fagard, 1974; Hansson \& Zweifler, 1974), twenty out of the present twenty-six patients showed a fall and in six the level was to less than $20 \%$ of the starting value. In three the level was unchanged (patients 17, 18 and 21, Table 1). There is certainly no clear relationship between the starting level of plasma renin and the subsequent fall in blood pressure as the fall in blood pressure, though greater in the high renin group, was not significantly greater than in the normal and low renin groups. Also some patients with a higher than normal renin were resistant to the effect of pindolol on blood pressure and others in whom there was a marked reduction of plasma renin to less than $20 \%$ of the starting value, showed no fall in pressure.

The addition of hydrochlorothiazide to the regime showed that it was possible to lower the blood pressure in all but one of the patients and neither the pre-thiazide plasma renin activity nor the change in plasma renin activity predicted the hypotensive effect. It might have been argued that if the plasma renin activity rose, the blood pressure would not fall or might even rise. The results in the present study do not support such an argument but show that a fall in blood pressure was associated with a rise in plasma renin activity when a thiazide is added to pindolol. In other studies, Bravo, Tarazi \& Dustan (1975) found that $\beta$-adrenoceptor blockade was much less effective in renin suppression when diuretic treatment was given previously. The results have been criticised (Davies \& Slater, 1975; McAllister, 1975) due to doubts about effective plasma levels of propranolol but those initial results of Bravo et al. 
$\stackrel{5}{5} \div$

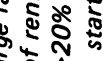

ㅇำ

甬昰 ミ

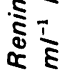

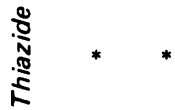

《芯 总

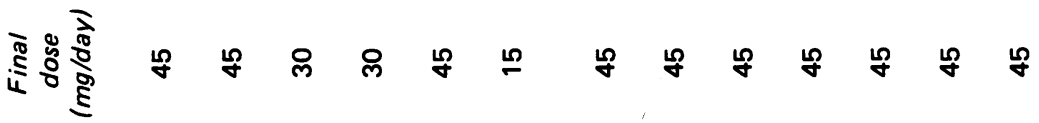

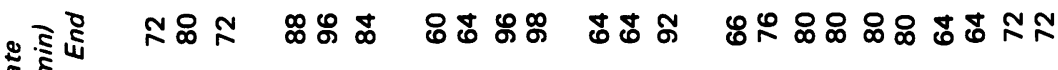
(1) ล뉸

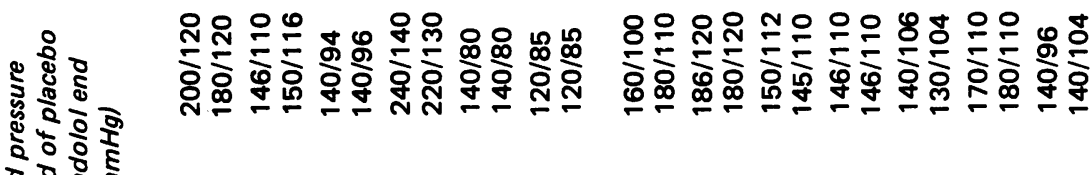

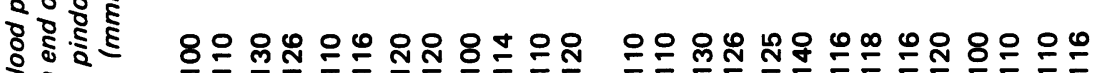

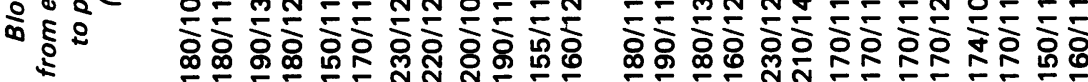

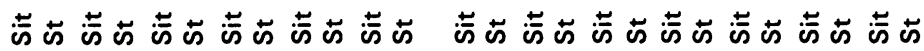

\. 3333333333333

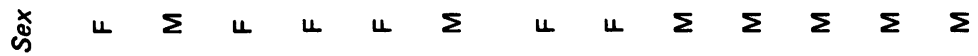

离

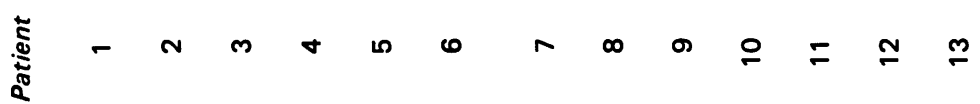

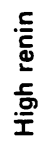

$\frac{\sqrt{5}}{2}$ 


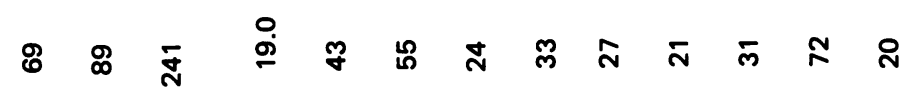

ลิ

일 \&

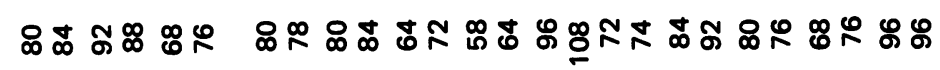

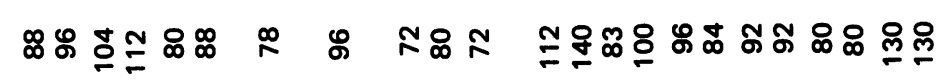

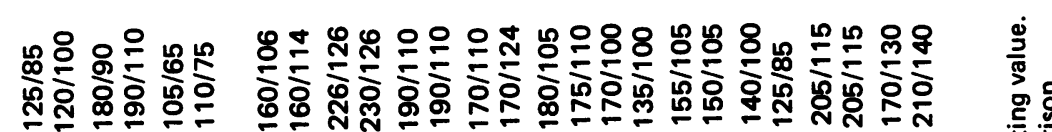

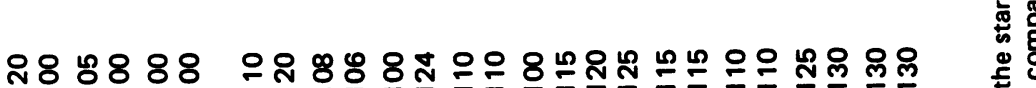

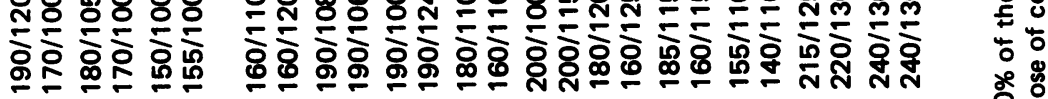

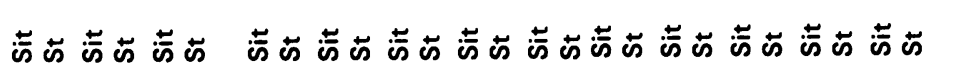

33000333000003300

$\sum$ แ 4 แ 4 แ $\Sigma$ แ แ 4 แ 4 แ

กิด

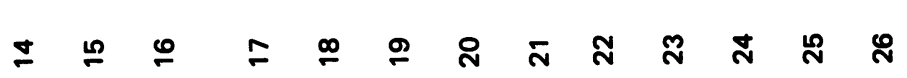




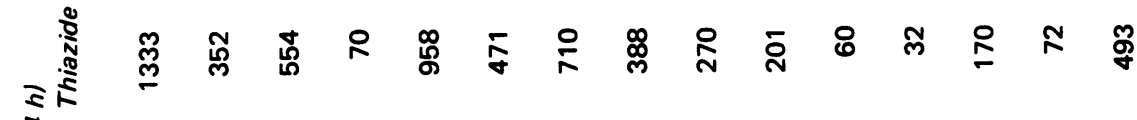
¿ุĩ

다

농

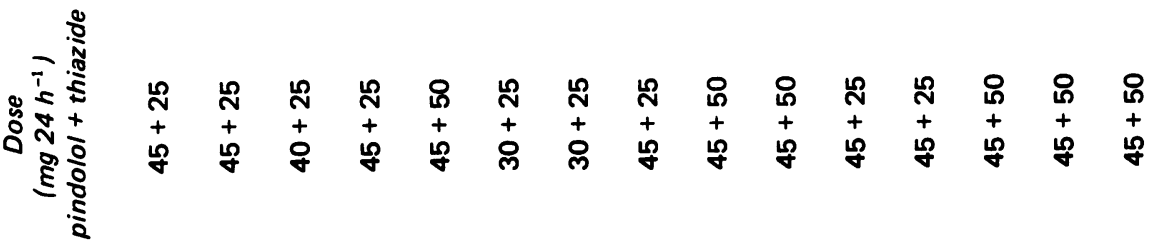

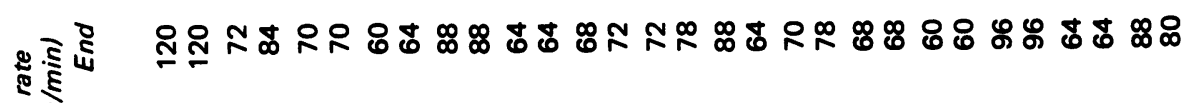

究

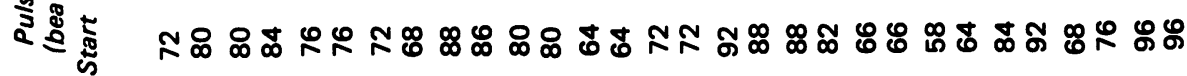

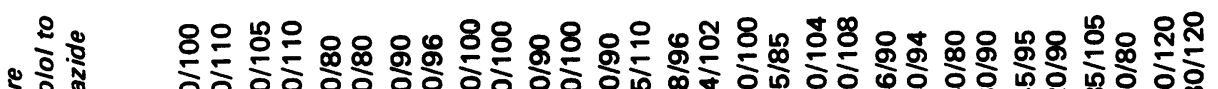

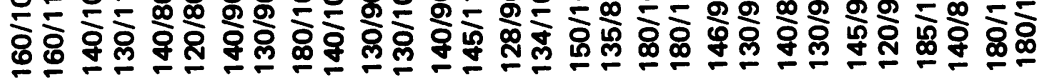

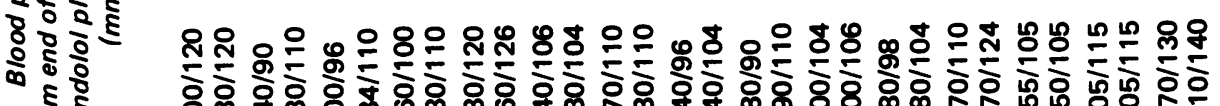

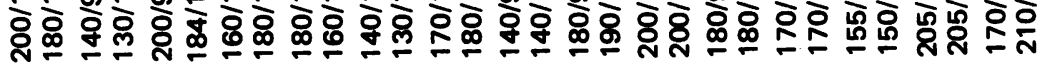

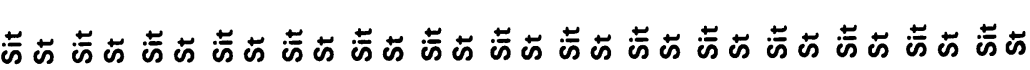
ㅇํㅇ 33333333333303030

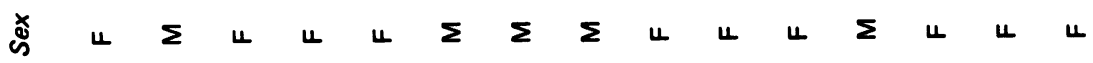

ஓ

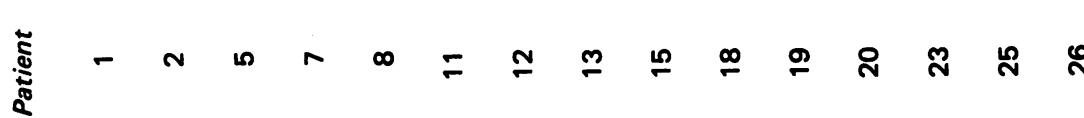


(1975) are very like the present ones with pindolol.

The most important general conclusion is that with normal or higher than normal plasma renin activity, the blood pressure can be lowered without any change in the plasma renin activity. Conversely, it is possible in some patients to markedly lower plasma renin activity without any change in blood pressure This is in accord with other studies, in particular Morgan et al. (1975). The original premise (Bühler et al., 1972) that $\beta$-adrenoceptor blockers like propranolol are particularly effective in lowering the pressure in those with high plasma renin activity and ineffective in those with normal or lower than normal plasma renin activity obviously requires qualification, and especially in the knowledge that different $\beta$-adrenoceptor blockers are presumably having different effects on the circulation independent of their effect on suppression of plasma renin activity. The present results refer only to plasma renin activity measured after $1 \mathrm{~h}$ of recumbency. It is possible that a more important

\section{References}

AMERY, A., BILlIET, L. \& FAGARD, R. (1974). Beta receptors and renin release. New Engl. J. Med., 290, 284.

BOYD, G.W., ADAMSON, A.R., FITZ, A.E. \& PEART, W.S. (1969). Radioimmunoassay determination of plasma-renin activity. Lancet, i, 213-218.

BRAVO, E.L., TARAZI, R.C. \& DUSTAN, H.P. (1975). $\beta$-adrenergic blockade in diuretic-treated patients with essential hypertension. New Engl. J. Med., 292, 66-70.

BÜHLER, F.R., LARAGH, J.H., BAER, L., VAUGHAN, E.D., Jr. \& BRUNNER, H.R. (1972). Propranolol inhibition of renin secretion: A specific approach to diagnosis and treatment of renin-dependent hypertensive diseases. New Engl. J. Med., 287, 1209-1214.

BÜHLER, F.R., LARAGH, J.H., VAUGHAN, E.D., Jr., GAVRAS, H., BRUNNER, H.R. \& BAER, L. (1973). The antihypertensive action of propranolol: specific anti-renin responses in high and normal renin essential, renal, renovascular and malignant hypertension. $\mathrm{Am}$. J. Cardiol., 32, 511-522.

DAVIES, R. \& SLATER, J.D.H. (1975). Effects of $\beta$-adrenergic blockade with propranolol. New Engl. J. Med., 292, 755-756.

DAY, M.D. \& ROACH, A.G. (1973). $\beta$-adrenergic receptors in the central nervous system of the cat concerned with control of arterial blood pressure and heart rate. Nature New Biol., 242, 30-31.

DOLLERY, C.T., LEWIS, P.J., MYERS, M.G. \& REID, J.L. (1973). Central hypotensive effect of propranolol in the rabbit. Br. J. Pharmac., 48, 343P.

FROHLICH, E.D., TARAZI, R.C., DUSTAN, H. \& measurement would be the degree of suppression over $24 \mathrm{~h}$ during normal activities. It is known, for example, that propranolol will block renin release by renal nerve stimulation (Johns \& Singer, 1974) which is probably related to blockade of the usual renin rise on upright posture (Michelakis \& McAllister, 1972). These authors were the first to point out the dissociation between a fall in plasma renin activity and blood pressure with propranolol, and a very full study has recently shown that plasma renin activity is reduced by much smaller doses than is blood pressure (Leonetti, Mayer, Morganti, Terzoli, Zanchetti, Bianchetti, Di Salle, Morselli \& Chidsey, 1975). The general conclusion would be that $\beta$-adrenoceptor blockers may lower the blood pressure in a variety of ways and that this may well be independent of any lowering or failure to lower plasma renin activity.

Thanks are due to Mrs Jennifer Dulieu for the renin activity estimations, and to Sandoz Ltd for supplies of pindolol.
PAGE, I.H. (1968). The paradox of $\beta$-adrenergic blockade in hypertension. Circulation, 37, 417-423.

GANONG, W.F. (1972). Effects of sympathetic activity and ACTH on renin and aldosterone secretion. In Hypertension 1972, ed J. Genest \& E. Koiw, pp. 4-14. Berlin/Heidelberg/New York: Springer-Verlag.

HANSSON, L. \& ZWEIFLER, A.J. (1974). The effect of propranolol on plasma renin activity and blood pressure in mild essential hypertension. Acta med. scand., 195, 397-401.

JOHNS, E.J. \& SINGER, B. (1974). Specificity of blockade of renal renin release by propranolol in the cat. Clin. Sci. mol. Med., 47, 331-343.

JULIUS, S., PASCUAL, A.V., ABBRECHT, P.H. \& LONDON, R. (1972). Effect of $\beta$-adrenergic blockade on plasma volume in human subjects. Proc. Soc. exp. Biol., N.Y., 140, 982-985.

LEONETTI, G., MAYER, G., MORGANTI, A., TERZOLI, L., ZANCHETTI, A., BIANCHETTI, G., DI SALLE, E., MORSELlI, P.L. \& CHIDSEY, C.A. (1975). Hypotensive and renin-suppressing activities of propranolol in hypertensive patients. Clin. Sci. mol. Med., 48, 491-499.

McAlliSTER, R,G. (1975). Letter to the Editor. New Engl. J. Med., 292, 756.

MICHELAKIS, A.M. \& MCALLISTER, R.G. (1972). The effect of chronic adrenergic receptor blockade on plasma renin activity in man. $J$. clin. Endocr., 34, 386-394.

MORGAN, T.O., ROBERTS, R., CARNEY, S.L., LOUIS, W.J. \& DOYLE, A.E. (1975). $\beta$-adrenergic receptor 
blocking drugs, hypertension and plasma renin. $B r . J$. clin. Pharmac., 2, 159-164.

STOKES, G.S., WEBER, M.A. \& THORNELL, I.R. (1974). Beta-blockers and plasma renin activity in hypertension. Br. med. J., 1, 60-62.

TARAZI, R.C. \& DUSTAN, H.P. (1972). $\beta$-adrenergic blockade in hypertension. Am. J. Cardiol., 29, 633-640.

VANDONGEN, R., PEART, W.S. \& BOYD, G.W. (1973). Adrenergic stimulation of renin secretion in the isolated perfused rat kidney. Circulation Res., 32, 290-296.

WEBER, M.A., THORNELL, I.R. \& STOKES, G.S.
(1974). Effects of beta adresergic blocking agents on plasma renin activity in the conscious rabbit. $J$. Pharmac. exp. Ther., 188, 234-240.

WERNING, V.C. \& VETTER, H. (1975). Visken-therapie bei grenzwert-hypertonie. Fortschr. Med., 93, 241-243.

WINER, N., CHOKSHI, D.S. \& WALKENHORST, W.C. (1971). Effects of cyclic AMP, sympathomimetic amines, and adrenergic receptor antagonists on renin secretion. Circulation Res., 29, 239-248.

(Received August 11, 1975) 